\title{
Oral manifestations in children with AIDS and in controls
}

\section{Manifestações bucais em crianças com AIDS e em controles}

\author{
Vera Lúcia BOSCO* \\ Esther Goldenberg BIRMAN**
}

\begin{abstract}
BOSCO, V. L.; BIRMAN, E. G. Oral manifestations in children with AIDS and in controls. Pesqui Odontol Bras, v. 16, n. 1, p. 07-11, jan./mar. 2002.

Thirty children with AIDS, aging 2 to 6 years, of both genders, treated as outpatients at the hospital Santa Casa de Misericórdia, São Paulo, were evaluated for oral manifestations and compared to a control group of age- and sex-matched healthy subjects. The correlation between oral lesions and the degree of immunosuppression was analyzed. The most prevalent oral manifestations - lymphadenopathy, followed by gingival alterations - were observed in the children with the highest levels of immunosuppression. Other manifestations observed in the AIDS group were: pseudomembranous and erythematous candidosis, enlargement of the parotids and ulcers. The results did not indicate a higher frequency of lesions. However, the observed oral manifestations had an early occurrence, which indicates that the early diagnosis is an important component in the management of those patients.
\end{abstract}

UNITERMS: Acquired immunodeficiency syndrome; Oral manifestations; Immunoblastic lymphadenopathy.

\section{INTRODUCTION}

Children infected with HIV develop severe immunosuppression. There is a short incubation period and several manifestations, including those of the oral tissues. Those lesions occur earlier in children than in adults and they facilitate the development of opportunistic infections, mainly those caused by fungi. The progression of the disease is swifter and more severe in children due to their developmental stage and to the immaturity of their immune system. The early diagnosis of lesions, as well as their complications, should be viewed as important components in the management and treatment of affected children ${ }^{3,5,7,17,18,28}$.

Several criteria for the evaluation of oral manifestations in different groups of children, either HIV-infected or not, are reported in the literature. Some of those criteria are: clinical features of the oral lesions, prevalence, relation between the HIV-associated lesions and the clinical stages of the syndrome and occurrence of secondary infections in HIV-positive pediatric subjects ${ }^{7,16,29}$. Several authors concluded that oral lesions are, very often, the only clinical signs of AIDS in children under 15 months of age. Pseudomembranous candidosis correlates with the prevailing immunological status, especially in symptomatic children. Re- duced $\mathrm{CD}^{+}$lymphocyte counts determine a greater frequency and severity of the manifestations associated with $\operatorname{AIDS}^{17,24,26}$.

Among the reports on AIDS, O'REILLY et al. ${ }^{20}$ (1982) and OLESKE et al. ${ }^{21}$ (1983) described unexplained cases of children with early immunosuppression associated to opportunistic infections favored by intrauterine or perinatal transmission. Other authors studied the opportunistic infections that affect children presenting with AIDS and children who are HIV-positive. They observed high frequencies of persistent oral candidosis, followed by enlargement of the parotids, cervicofacial lymphadenopathy and herpes simplex. They considered that oral candidosis and the enlargement of the parotids are important aspects to be taken into account when deciding on adequate treatments for children with AIDS - oral candidosis is a marker of the progression of the disease $e^{2,4,5,6,8,9,13,15,18,22,23,24,25,27}$.

So, our aim was to evaluate the oral manifestations of Brazilian pediatric outpatients with AIDS, who were being treated with antiviral drugs, as well as to analyze the correlation between oral manifestations and the degree of immunosuppression. Those children were compared with clinically healthy children without a history of associated risk factors.

\footnotetext{
*PhD, Pediatric Dentistry, Federal University of Santa Catarina, Brazil.

** Professor and Chair, Oral Diagnosis, University of São Paulo, Brazil.
} 
BOSCO, V. L.; BIRMAN, E. G. Oral manifestations in children with AIDS and in controls. Pesqui Odontol Bras, v. 16, n. 1, p. 07-11, jan./mar. 2002.

\section{CASUISTIC, MATERIALS AND METHODS}

Thirty patients aging from 2 to 6 years, of both genders, under treatment and ambulatorial care at the Pediatric Infectology Center (Santa Casa de Misericórdia, São Paulo, Brazil) were evaluated for oral lesions, without any consideration regarding dental caries. The children were born from HIV-positive mothers, presenting with anti-HIV serum, positively detected by means of ELISA and Western Blot tests after 15 months of age. Updated CD4 ${ }^{+}$ counts and data on the utilized medication were obtained from patients' records. Each child was examined for $\mathrm{CD}^{+}$counts only once, two to three months before clinical examination.

The selected subjects were symptomatic children with AIDS, under constant and regular treatment with drugs such as trimethropin-sulfamethoxazol (Bactrin - Roche) or antiretroviral agents such as zidovudine (AZT-Retrovir - Glaxo Welcome), didanosine (ddI) (VIDEX - Bristol-Myers Squibb), and/or 2-dioxy-3-tiacitidine (3TC or Epivir - Glaxo Welcome).

Thirty sex- and age-matched children, without history of blood transfusion or associated risk factors, were included as controls.

Under artificial light, the patient's face was visually inspected and the head and neck regions were palpated in order to evaluate the ganglionar net and the parotid glands. Moving aside the lips with a wooden spatula, intraoral examination was performed. A single examiner carried out clinical procedures and charting. The diagnosis of lesions was based on the criteria proposed by the World Health Organization in $1993^{11}$. The study was approved by the Ethics Committee, Santa Casa de Misericórdia, and informed consents were obtained from parents and/or person responsible for

TABLE 1 - Distribution of children with AIDS - age range and $\mathrm{CD}^{+}{ }^{+}$counts.

\begin{tabular}{l|c|c|c|c}
\hline \hline $\begin{array}{c}\text { Age } \\
\text { range }\end{array}$ & $\begin{array}{c}\text { Absence of } \\
\text { suppression } \\
(\geq 1,000 \\
\left.\text { cells } / \mathrm{mm}^{3}\right)\end{array}$ & $\begin{array}{c}\text { Moderate } \\
\text { suppression } \\
(500-999 \\
\left.\text { cells } / \mathrm{mm}^{3}\right)\end{array}$ & $\begin{array}{c}\text { Severe } \\
\text { suppression } \\
(<500 \\
\left.\text { cells } / \mathrm{mm}^{3}\right)\end{array}$ & Total \\
\hline $\begin{array}{l}2 \vdash 4 \\
\text { years }\end{array}$ & - & 4 & 2 & 6 \\
\hline $\begin{array}{l}4 \vdash \mid 6 \\
\text { years }\end{array}$ & - & 6 & 18 & 24 \\
\hline Total & 0 & 10 & 20 & 30 \\
\hline \hline
\end{tabular}

the children of both groups, before the beginning of the investigation.

\section{Statistical analysis}

The chi-square test $\left(\chi^{2}\right)$ was used to determine the degree of immunosuppression.

\section{RESULTS}

The age range and $\mathrm{CD} 4^{+}$counts of children with AIDS are presented in Table 1. None of the children of that group were free of immunosuppression $\left(\geq 1,000\right.$ cells $/ \mathrm{mm}^{3}$ ). Moderate (500-999 cells $\left./ \mathrm{mm}^{3}\right)$ and severe $\left(<500\right.$ cells $\left./ \mathrm{mm}^{3}\right)$ suppression levels were detected in 33.33\% (10/30) and $66.67 \%(20 / 30)$ of the subjects, respectively, but this difference in frequency was not statistically significant $\left(\chi^{2}=2.11\right)$. The types of orofacial manifestations found in the children with AIDS are presented in Chart 1 . From the 30 studied children, $40 \%(12 / 30)$ presented with cervicofacial lymphadenopathy; nonspecific gingivitis prevailed in children with moderate to severe suppression $33.33 \%(10 / 30)$-, candidosis was observed in $23.33 \%(7 / 30)$, enlargement of the parotid glands in $13.33 \%(4 / 30)$ and ulcerations in $3.33 \%(1 / 30)$. Some children presented with more than one lesion. The distribution of orofacial lesions is shown in Table 2. Out of the children with lymphadenopathy, $33.33 \%$ (4/12) presented with moderate suppression and $66.67 \%(8 / 12)$, with severe suppression. With respect to candidosis, $28.57 \%(2 / 7)$ of the cases were associated to moderate suppression, $71.43 \%(5 / 7)$ to severe suppression and none of them was associated to the absence of suppression. Enlargement of the parotid glands was observed in four children, from which $25 \%$ (1/4) presen-

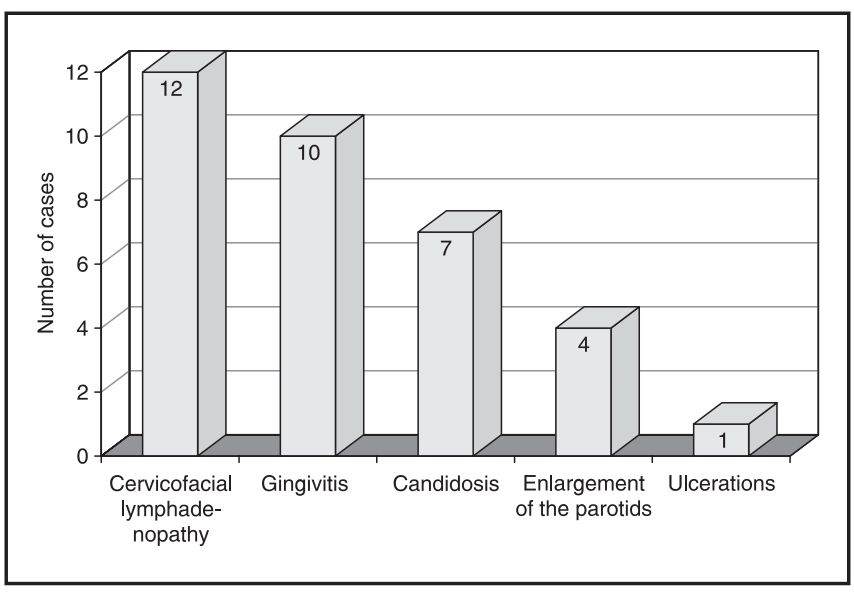

CHART 1 - Orofacial manifestations detected in children with AIDS. 
BOSCO, V. L.; BIRMAN, E. G. Oral manifestations in children with AIDS and in controls. Pesqui Odontol Bras, v. 16, n. 1, p. 07-11, jan./mar. 2002.

TABLE 2 - Orofacial manifestations diagnosed in the group of children with AIDS, according to CD4+ counts.

\begin{tabular}{l|c|c|c|c}
\hline \hline $\begin{array}{c}\text { Orofacial } \\
\text { manifes- } \\
\text { tations* }\end{array}$ & $\begin{array}{c}\text { Absence of } \\
\text { suppression } \\
(1,000 \\
\left.\text { cells } / \mathrm{mm}^{3}\right)\end{array}$ & $\begin{array}{c}\text { Moderate } \\
\text { suppression } \\
(500-999 \\
\left.\text { cells } / \mathrm{mm}^{3}\right)\end{array}$ & $\begin{array}{c}\text { Severe } \\
\text { suppression } \\
(<500 \\
\left.\text { cells } / \mathrm{mm}^{3}\right)\end{array}$ & Total \\
\hline $\begin{array}{l}\text { Lymphade- } \\
\text { nopathy }\end{array}$ & 0 & 4 & 8 & 12 \\
\hline Gingivitis & 0 & 4 & 6 & 10 \\
\hline Candidosis & 0 & 2 & 5 & 7 \\
\hline $\begin{array}{l}\text { Enlargement } \\
\text { of the parotids }\end{array}$ & 0 & 1 & 3 & 4 \\
\hline Ulcerations & 0 & 0 & 1 & 1 \\
\hline $\begin{array}{l}\text { Total of } \\
\text { lesions }\end{array}$ & 0 & 11 & 23 & 34 \\
\hline \hline
\end{tabular}

*Some chidren presented with more than one type of orofacial manifestation. Number of evaluated children $=30$.

ted moderate suppression and 75\% (3/4), severe suppression; ulceration was found in only one child with severe suppression. Orofacial manifestations were not detected in the control group.

\section{DISCUSSION}

The number of registered pediatric cases of AIDS does not reflect the impact of this epidemic, which has increased. Indeed, it could become one of the fifth major causes of child mortality worldwide, although the new drugs currently available are beginning to reverse this picture. Since the oral cavity can be easily examined during clinical evaluation, it is the first anatomical site reported to show signs that are indicative of AIDS. Oral manifestations and their various aspects should be checked, and it is important to seek not only their diagnosis but also a delineation of their prognosis and adequate treatment ${ }^{7,8,13}$. Among the detected lesions, cervicofacial lymphadenopathy was the most frequent finding in our sample. Some authors have diagnosed this manifestation at lower frequencies. In our study, it prevailed in children with marked immunosuppression ${ }^{1,4,10}$. The relationship between cervicofacial lymphadenopathy and HIV has not been fully established to date; this oral abnormality could, however, result from changes in the immune status of the HIV carrier, with reduction in the number of $\mathrm{CD}^{+} \mathrm{T}$ cells and/or modification of the $\mathrm{CD} 4 / \mathrm{CD} 8$ ratio $^{4}$. With respect to gingivitis, we observed local or generalized changes in color, shape and/or volume, but no linear gingival erythema was noted. Considering other issues, such as malnutrition, loss of immunity and, especially, local problems like poor hygiene or lack of hygiene, any conclusions regarding children are still premature. Gingivitis prevailed in children with moderate to severe suppression, at varied frequencies. Differently from our results, higher frequencies of gingivitis have been previously reported ${ }^{6,19}$.

Microbiological analysis detected candidosis, predominantly the pseudomembranous type, followed by the erythematous type, associated to moderate to severe immunosuppression, as it has been reported in other studies ${ }^{8,9,22}$. Considered as a diagnostic factor, candidosis in children may act as a marker of the fast progression of the disease, unlike the enlargement of the parotid gland, which progresses at a slower pace. The presence of C. albicans may indicate the beginning of the infection in individuals affected by AIDS or other diseases, which justifies the need for its early detection. Children with AIDS presented almost exclusively C. albicans in their oral microbiota, while the control group presented a higher diversity of oral yeast species. That fact is related to the utilized medication, which could favor the development of C. albicans. The frequency of candidosis bears an important relation with extrinsic factors such as treatment and hospitalization. In our study, the low levels of clinical manifestations might be accounted not only by the treatment in use but also by the ambulatorial regimen ${ }^{8,13,14,19,26}$.

With respect to the enlargement of the parotid gland, its etiology is still obscure. It affects 11 to $17 \%$ of the children presenting with AIDS and is usually associated with generalized or intraparotidal lymphadenopathy, with possible lymphoplasmocytic infiltrate, cystic lesions and lymphomas in the gland's core. Cervicofacial lymphadenopathy has been previously detected at lower frequencies, as well as the enlargement of the parotid glands. In the evaluation of the levels of suppression, we observed that children with severe suppression were more affected by lymphadenopathy, although this manifestation has been associated with a better prognosis regarding the progression of the disea$\mathrm{se}^{4,13,25,26}$.

Ulcerations, which are commonly observed in AIDS, have received numerous denominations. Their classification is a difficult task, not only in view of the varied etiologies, which do not allow for 
BOSCO, V. L.; BIRMAN, E. G. Oral manifestations in children with AIDS and in controls. Pesqui Odontol Bras, v. 16, n. 1, p. 07-11, jan./mar. 2002.

a more definite diagnosis, but also due to the scarcity of cases in the present study. Several terms have been used to name this group of oral abnormalities, such as recurrent aphthous ulceration, unidentified ulceration, ghost ulceration and others, but they definitely need to be reevaluated in pediatric patients. It is worth mentioning that the occurrence of manifestations is subject to alterations, which are possibly related to current approaches, treatments and to the utilization of new drugs, as well as it happens with adults. Linear gingival erythema itself, as well as hairy leukoplakia, have been increasingly detected in children ${ }^{2,23}$. In this study, such manifestations, as well as angular cheilitis, herpes simplex and petechiae, were not found. This can be attributed to the small frequency of these manifestations in children presenting with AIDS. The early diagnosis and the un- derstanding of pediatric AIDS have demonstrated the effectiveness of some measures that resulted in less frequent orofacial manifestations, while further progress awaits the release of novel approaches.

\section{CONCLUSIONS}

The analysis of the reported results allowed us to conclude that orofacial manifestations within the AIDS group were more prevalent in children with moderate and severe immunosuppression, especially cervical lymphadenopathy, followed by gingivitis. Manifestations were not observed in the absence of immunosuppression. The reduced frequency of other lesions in children presenting with AIDS indicated changes that can be due to the utilization of anti-retroviral drugs.

BOSCO, V. L.; BIRMAN, E. G. Manifestações bucais em crianças com AIDS e em controles. Pesqui Odontol Bras, v. 16 , n. 1 , p. $07-11$, jan./mar. 2002.

\begin{abstract}
Trinta crianças portadoras de AIDS, entre dois e seis anos, de ambos os sexos, em tratamento ambulatorial na Santa Casa de Misericórdia de São Paulo foram avaliadas quanto às manifestações bucais presentes. Estas foram pareadas por sexo e idade, como controle, a um grupo de crianças sadias, correlacionando-as à presença de lesões e ao grau de imunossupressão. As manifestações bucais mais prevalentes foram observadas nas crianças com maior grau de imunossupressão, representadas principalmente pela linfoadenopatia e pelas alterações gengivais. Candidoses pseudomembranosas eritematosas foram manifestações significativas observadas no grupo AIDS, tendo sido observadas em menor número as alterações gengivais, o aumento da glândulas parótidas e as ulcerações. Os resultados não indicaram maior freqüência de lesões presentes; contudo, as manifestações bucais ocorreram precocemente, indicando que o diagnóstico precoce é um componente importante no manejo destas crianças.
\end{abstract}

UNITERMOS: Sindrome de imunodeficiência adquirida; Manifestações bucais; Linfadenopatia imunoblástica.

\section{BIBLIOGRAPHIC REFERENCES}

1. BUNDZMAN, E. R.; NEVES, A. A.; SANTOS, L. C.; OLIVEIRA, R. H. S. Relação entre linfadenopatia, imunossupressão e manifestações orais em crianças HIV+. In: REUNIÃO ANUAL DA SOCIEDADE BRASILEIRA DE PESQUISA ODONTOLÓGICA, 13, 1996, Águas de São Pedro. Anais... 1996. p. 109.

2. CASTRO, G. F.; SOUZA, I. P. R.; FONSECA, R. et al. Freqüência de manifestações bucais em crianças infectadas pelo HIV. In: REUNIÃO ANUAL DA SOCIEDADE BRASILEIRA DE PESQUISA ODONTOLÓGICA, 15, 1998, Águas de São Pedro. Anais... 1998. p. 154.

3. CECCOTTI, E. Niños con SIDA. Manifestaciones bucales. Rev Asoc Odontol Argentina, v. 83, n. 4, p. 299-303, oct./dic. 1995.

4. CHAN, A.; MILNES, A.; KING, S. M.; READ, S. The relationship of oral manifestations to parameters of immune function and CDC stage in children born to HIV-positive women. Pediatric AIDS and HIV infection: fetus to adolescents, v. 5, n. 2, p. 101-107, Apr. 1994.

5. CHIGURUPATI, R.; RAGHAVAN, S. S.; STUDEN-PAV-
LOVICH, D. Pediatric HIV infection and its oral manifestation: a review. Pediatr Dent, v. 18, n. 2, p. 106-113, Apr./May 1996.

6. CHIODO, M.; GALLI, L.; MANELLI, F. et al. Oral lesions in HIV-positive children. In: INTERNATIONAL WORKSHOP ON THE ORAL MANIFESTATIONS OF HIV INFECTION, 3, Annals... London, May/June 1996.

7. COSTA, L. R. R. S.; VILLENA, R. S.; BIRMAN, E. G. AIDS in children: an up to date review of stomatological aspects. Rev FOLA/Oral, v. 2, n. 1, p. 21-25, Jan./Feb. 1996.

8. COSTA, L. R. R. S.; VILLENA, R. S.; BIRMAN, E. G. Oral findings in pediatric AIDS: a case control study in Brazilian children. J Dent Child, v. 65, n. 3, p. 186-190, May/June 1998.

9. DEL TORO, A.; BERKOWITZ, R. J.; FRENKEL, L.; MEYEROWITZ, C. HIV-related oral findings in HIV-infected children. Pediatr Dent, v. 17, n. 2, p. 145, Mar./Apr. 1995.

10. DEL TORO, A.; BERKOWITZ, R. J.; MEYEROWITZ, C.; FRENKEL, L. M. Oral findings in asymptomatic (P-1) and symptomatic (P-2) HIV-infected children. Pediatr Dent, v. 18, n. 2, p. 114-116, Apr./May 1996. 
BOSCO, V. L.; BIRMAN, E. G. Oral manifestations in children with AIDS and in controls. Pesqui Odontol Bras, v. 16, n. 1, p. 07-11, jan./mar. 2002.

11. EC-CLEARINGHOUSE ON ORAL PROBLEMS RELATED TO HIV INFECTION; WHO COLLABORATING CENTRE ON ORAL MANIFESTATIONS OF THE IMMUNODEFICIENCY VIRUS. Classification and diagnostic criteria for oral lesions in HIV infection. J Oral Pathol Med, v. 22, n. 7, p. 289-291, Aug. 1993.

12. FONSECA, R.; CARSOSO, A. S.; POMARICO, I. P. R. Frequency of oral manifestations in children with human immunodeficiency virus. Quintessence Int, v. 31, n. 6, p. 419-422, June 2000.

13. GRANDO, L. J. Perfil social, manifestações estomatológicas e detecção dos vírus CMV, EBV, HPV e HSV na cavidade bucal de crianças brasileiras e norte-americanas infectadas pelo HIV. Porto Alegre, 2000, 197 p. Tese (Doutorado em Odontopediatria). Pontificia Universidade do Rio Grande do Sul.

14. HOWELL, R. B.; JANDINSKY, J.; PALUMBO, P. et al. Oral soft tissue manifestations and CD4 lymphocyte count in HIV-infected children. Pediatr Dent, v. 18, n. 2, p. 117-120, Mar./Apr. 1996.

15. KATZ, M. H.; MASTRUCCI, M. T.; LEGGOTT, P. J. et al. Prognostic significance of oral lesions in children with perinatally acquired human immunodeficiency virus infection. J Dent Child, v. 147, n. 1, p. 45-48, Jan. 1993.

16. KETCHEM, L.; BERKOWITZ, R. J.; McILVEEN, L. et al. Oral findings in HIV-seropositive children. Pediatr Dent, v. 12, n. 3, p. 143-146, May/June 1990.

17. KLINE, M. V. Oral manifestation of pediatric human immunodeficiency virus infection: a review of the literature. Pediatr, v. 97, n. 3, p. 380-388, Mar. 1996.

18. LEGGOTT, P. J.; ROBERTSON, P. B.; GREENSPAN, D. et al. Oral manifestations of primary and acquired immunodeficiency diseases in children. Pediatr Dent, v. 9, n. 2, p. 98-104, Mar. 1987.

19. LEGGOTT, P. J. Oral manifestations of HIV infection in children. Oral Surg Oral Med Oral Pathol, v. 73, n. 2, p. 187-192, Feb. 1992.
20. MONIACI, D.; CAVALLARI, M.; GRECO, D. et al. Oral lesions in children born to HIV-1 positive women. J Oral Pathol Med, v. 22, n. 1, p. 8-11, Jan. 1993.

21. OLESKE, J.; MINNEFOR, A.; COOPER, R. et al. Immune deficiency syndrome in children. J Am Med Assoc, v. 249, n. 17, p. 2345-2349, May 1983.

22. O'REILLY, R.; KIRKPATRICK, D.; SMALL, C. B. et al. Unexplained immunodeficiency and opportunistic infections in infants. Morb Mortal Mkly Rep, v. 31, n. 49, p. 665-667, Dec. 1982.

23. RAMOS-GOMEZ, F. J.; PETRU, A.; HILTON, J. F. et al. Orofacial manifestations, caries, and periodontal status in pediatric HIV infection. Pediatr Dent, v. 16, n. 2, p. 159-160, Mar./Apr. 1994.

24. RAMOS-GOMES, F. J.; HILTON, J. F.; CANCHOLA, A. J. et al. Risk factors for HIV-related soft-tissue manifestations in children. Pediatr Dent, v. 18, n. 2, p. 121-126, Apr./May 1996.

25. RAMOS-GOMEZ, F. J. Oral aspects of HIV infection in children. Oral Dis, v. 3, Suppl 1, p. S31-S35.

26. SANTOS, L. C.; TURA, L. F. R.; SOUZA, I. P. R. Relação entre o grau de imunossupressão e manifestações orais em crianças HIV+. In: REUNIÃO ANUAL DA SOCIEDADE BRASILEIRA DE PESQUISA ODONTOLÓGICA, 14, 1997, Águas de São Pedro. Anais... 1997. p. 122.

27. TOVO, P. A.; DE MARTINO, M.; GABIANO, C. et al. An Italian register for HIV infection in children. Prognostic factors and survival in children with perinatal HIV-1 infection. The Lancet, v. 339, p. 1249-1253, May 1992.

28. VALDEZ, I. H.; PIZZO, P. A.; ATKINSON, J. C. Oral health of pediatric AIDS patients: a hospital-based study. ASDC J Dent Child, v. 61, n. 2, p. 114-118, Mar./Apr. 1994.

29. VILAÇA, E. N.; LINHARES, R. M. S.; PORDEUS, I. A. Manifestações bucais associadas à infecção pelo HIV/AIDS em crianças. Rev CROMG, v. 7, n. 1, p. 47-56, jan./abr. 2001.

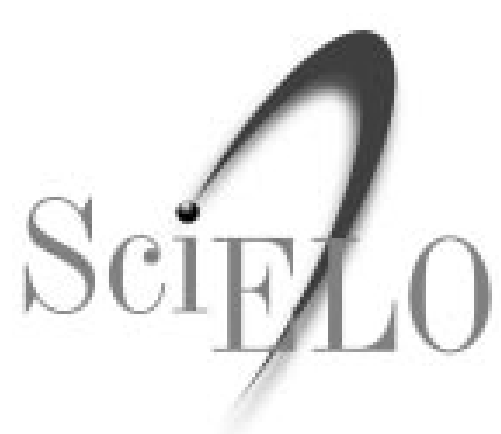

http://wwww.scielo.br

\section{As publicações científicas brasileiras estão ao alcance de suas mãos. Não importa em que parte do mundo você esteja}

SciELO - Scientific Electronic Library Online é uma biblioteca de revistas científicas disponível na Internet. Uma biblioteca virtual que reúne 64 publicações científicas brasileiras. Sua interface permite o acesso fácil aos textos completos de artigos científicos, por meio das tabelas de conteúdos dos números individuais das revistas ou da recuperação de textos por nome de autor, palavras-chaves, palavras do título ou do resumo. 